\title{
Legitimating THE RETURN OF IMMigRANTS in Spanish Media Discourse
}

\begin{abstract}
The article presents the analysis of a set of articles published in a Spanish newspaper on the return plan for immigrants. Since the data indicate that the plan is described as a phenomenon that is positive both for immigrants and for Spain, it is documented here how the newspaper legitimates the plan by presenting it to its local readers. Attention is paid to how immigrants are represented both linguistically and visually and how this form of representation actually reveals the newspaper's elite racist attitudes. The analysis, grounded in multimodal analysis and critical discourse analysis, contributes towards the study of the discursive representation of minority groups as "others" and extends the existing research by documenting how political measures against such minorities are discursively presented as actually being in their own interests.
\end{abstract}

Key words

Legitimation; immigration; multimodality; visual grammar; critical discourse analysis; press; representation of social actors

\section{Introduction}

The discursive representation of immigrants in the press has had a long tradition (Alonso et al. 2010; Bañón 2002, 2007; Reisigl and Wodak 2001; van Dijk 2003, 2005); these studies have pointed out the main linguistic and visual characteristics used to represent immigrants and the effect of their representation in the audience. The aim of the article is to trace how immigrants are represented and how the recent Spanish political plan of returning the immigrants to their countries of origin legitimates discursively legitimates this practice. In this sense the 
newspaper under analysis is biased in that it represents the issue in such a way as to legitimate the return of immigrants at a time of economic crisis, thus articulating the official governmental policy (Chouliaraki 2007; Chovanec 2010; van Leeuwen 2007).

The economic crisis that Spain has suffered in recent years has implied a process of economic decline that has affected the entire working class (both, immigrant and local workers as a whole), as well as middle class. Corruption, overspent money and social investment cuts have been the main reasons that have contributed to the socio-economic crisis in Spain. For this reason, observing the increase of unemployment, the Spanish Government created a plan for the voluntary return of immigrants in November 2008 so that those who had no job could go back to their countries. Returnees would receive $40 \%$ of the money they deserved for being on the dole before leaving Spain and the other $60 \%$ on arrival to their countries. In this sense, it is crucial to mention that the Return Plan was born and started to be executed under a socialist Government and it has been carried out in part under a conservative one since Spain had elections in 2011 and the Government was changed.

The Government requested that immigrants willing to follow this plan must have spent more than six months in Spain. In addition, the non-governmental organizations assisting immigrants to take the necessary steps to return according to this plan would be required to prepare a report stating that there was a need for economic help before the return ticket fares, and some money to facilitate their integration into their country would be paid (Red Europea de Migraciones 2009European Network of Migrations).

This article documents how the issue of immigrants' return is represented in the press in a newspaper published in Alicante, the city with the third highest number of immigrants in Spain. The main research questions are the following: what are the main linguistic and visual characteristics of the news items on the Return Plan in the newspaper Información? What are the main strategies used to legitimate the Plan and to present it as something positive in the said newspaper?

Información has been selected because it is the most well-known in Alicante and is read by $60 \%$ of those who read a newspaper every day in Alicante. This newspaper was created in 1941 after the closing of the communist newspaper Nuestra Bandera (Our Flag). The political leaning of the newspaper at the moment is centre-left. Información sold 25022 copies on average each day in 2011. The editorial office is in Alicante, which is the capital city, although it has branches in some cities and towns near Alicante (Martínez Lirola 2013).

The return of immigrants to their countries of origin is a complex process that has been studied in the social sciences (Conway and Potter 2009; Long and Oxfeld 2004) but it needs further research. For this reason, it seems necessary to shed light on the verbal and visual elements used by the media to talk about the Return Plan. Critical Discourse Analysis can complement previous research because it allows us to observe the dominant discourses about immigrants' return by paying attention to the general linguistic and visual characteristics of pieces of 
news dealing with immigrants' return. We will mainly concentrate on the image, its caption, the heading and the subheading on a sample of pieces of news published between September 2008 and March 2011 in the newspaper Información since they are the textual elements that contribute more fully to catching the readers' attention.

This article is organised as follows: the next section will concentrate on the theoretical framework. Section three is devoted to the results, paying attention to the general description of instances of return in the newspaper Información and to the specific analysis of four multimodal texts in this newspaper. The fourth section will pay attention to the function of the media and elite racism. The article will finish with some conclusions based on the analysis.

\section{Theoretical framework}

Media analysis can contribute to the understanding of different social realities such as the arrival or the return of immigrants to a particular society. Media offer information that is considered true for different readers, i.e., there are people who are not critical with the information offered. The texts produced by media are invariably framed in a particular social context since they are produced by authors who are socio-economic actors in their time (Martin and Rose 2007; Reisigl and Wodak 2001; Renkema 2009; Woods 2007). Fairclough (1995) van Dijk (1987, 2007), van Leeuwen $(2005,2009)$ and others have developed a method of analysis through CDA in order to deconstruct the meanings of different texts.

In this sense, critical discourse analysis (CDA) can be helpful in the study of print media because CDA pays attention to dominant discourses in the society in order to decode how discourse reproduces power and to unveil situations of injustice and social realities such as immigration. Consequently, one of the main purposes of CDA is to increase the critical consciousness of society when facing the discourse of power.

The discourse of the media, especially the news media, contains discursive elements that reinforce and reproduce the supremacy of the white elites over the less favoured social groups (Crespo and Martínez Lirola 2012; Martínez Lirola 2010; van Dijk 2003, 2005). In other words, the media reproduce discourses on social inequality. For this reason, studies have used CDA in order to analyse how the written press presents ethnic minorities and immigrants (Martínez Lirola 2008; van Dijk 1993, 2008; van Leeuwen 2005, 2009).

This paper will look specifically at the representation of social actors. Following van Leeuwen (2008), we will apply the principles of CDA to the analysis of social actors in discourse, i.e., it will be observed how the represented participants are realized linguistically: as agents or as patients, impersonally or personally, individually or collectively, etc., which has an effect on the way readers perceive the social representation of the different participants that appear in discourse. In addition, following van Leeuwen (2008), we will also show that this analysis can 
be applied to visual representations since images always provide interpretations that affect the way in which viewers perceive the participants represented in images.

Moreover, multimodality can add to CDA because it concentrates on the way different modes of communication express meaning in texts. Our society accords power to visual elements due to their importance in catching the readers' attention. Therefore, many texts in our social context are multimodal in nature, i.e., they combine different modes of communication such as written text, photographs, music, diagrams, etc. (Baldry 2000; Baldry and Thibault 2006; Jewitt 2009; Kress 2003; Kress and van Leeuwen 2001, 2006; O'Toole 2011; Royce and Bowcher 2007; van Leeuwen and Jewitt 2000). Some of these authors point out that power relations can be drawn out not only through textual analysis but by applying the same kind of critical rigor to the images (see also Talbot 2003; Thompson 1990). In this paper, we follow the principles of visual grammar proposed by Kress and van Leeuwen's (2006) because they are useful to deconstruct the photographs found in the texts under analysis and their main visual characteristics.

The image of immigrants in the press has been studied extensively using critical discourse analysis (CDA) as a perspective (Cottle 2000; van Dijk 1987, 2003, 2008; Wimmer 2000; Wodak and Reisigl 2001, inter alia). The main areas of study in Spain have been the analysis of stereotypes, the elite discourse on immigration and the main topics that appear on the press related to immigration, i.e., the first moment of arrival in small boats, the jobs done by immigrants, problems with the main group of society, the association between immigration and delinquency, among others.

Legitimation is an important concept in CDA and in this article in order to deconstruct the way in which the news items under analysis legitimate the return of immigrants; legitimation is understood as the "widespread acknowledgement of the legitimacy of explanations and justifications of how things are done" (Fairclough 2003: 219). In general, the press highlights a contrast between positive and negative legitimating values (Fowler 1991; Caldas-Coulthard 2002) that contributes to the dichotomy 'we' vs. 'they' (van Dijk 1993, 2005), as we will see in this article.

The arrival of immigrants to Spain from the late 90s until the present has also contributed to the development of studies that concentrate on different topics. For example, there are some books on the relationship between immigration and political discourse (Checa 2008; Zapata Barrero 2008). Nash (2001) and Retis (2010) have done some studies on immigration and genre. Moreover, there are other authors that pay attention to the discursive representation of immigrants in the press (Alonso Belmonte et al. 2010; Bañón 2002, 2007; Granados 1998; Martínez Lirola 2006, 2008, 2009, 2014, inter alia).

However, although there are international studies on how the return home of immigrants is portrayed in the social sciences, as already stated in the previous section, there are no studies on its portrayal in the press and there are very few that concentrate on the return of immigrants in Spain (Blázquez Vilaplana 2013; Martínez Lirola 2013). In general, the fact of returning is presented as something 
positive that benefits immigrants. Nevertheless, immigrants' voices hardly ever appear in these pieces of news (Alonso Belmonte et al. 2010).

For this reason, this article will concentrate on all the pieces of news dealing with immigrants' return in the newspaper Información. These pieces of news are produced and consumed in a context of socio-economic crisis with a high percentage of the population being on the dole (Conway and Potter 2009; Red Europea de Migraciones 2009).

\section{Methodology and data}

As regards methodology, we started compiling all the news items dealing with immigrants' return published in the newspaper Información from September 2008 to March 2011. This specific period was chosen because it coincides with the beginning of the Return Plan. After the compilation of the corpus we studied the main linguistic and visual characteristics used in the texts to talk about the return plan. CDA and specifically van Leeuwen's (2008) representation of social actors were chosen as theoretical frameworks. The fact of having some texts with items made us also use Kress and van Leeuwen's (2006) visual grammar in order to deconstruct the visuals.

Our analysis is mainly qualitative, following the tradition of critical discourse analysts. For this reason, we offer a detailed analysis of two texts that are representative of the main linguistic and visual characteristics found in the texts compiled. Nevertheless, the quantitative data presented in section 4.1 is provided in order to offer a preliminary context, i.e., it is just a quantitative overview of the wider coverage on immigration in the newspaper because the purpose of the article is to focus in depth upon a key section of that coverage, exploring (through visual grammar and linguistic analysis) what images of immigrants are being created to refer to the return of immigrants.

As regards data, the newspaper Información was selected in order to observe the discursive representation of immigrants' return in a local newspaper published by Spanish people in Alicante. This city has been chosen because it receives most immigrants in the region of Valencia and is situated in one of the Spanish provinces with a high percentage of immigration, around $18 \%$. Moreover, Alicante is the fifth city after Madrid, Barcelona, Murcia and Valencia, in terms of the number of immigrants who have followed the Return Plan.

All in all, 132 articles were obtained from the online archives of the newspaper Información during the period of two and a half years from September 2008 to February 2011. Out of those 132 news items 42 dealt with the Return Plan: 61.9\% were published in $2009 ; 28.5 \%$ in 2008 and $9.5 \%$ in 2010 . There were just $11.9 \%$ that concentrated on the return process undertaken by various nationalities (Ecuador, Romania, Bolivia and Peru).

For the sake of imposing limitations, out of the 42 pieces of news related to the Return Plan, two texts have been selected: text 1, date: 20 September 2008 and 
text 2, date: 25 June 2009. These texts include both words and images, and therefore provide an opportunity to show interaction between these different modes in conveying information about the Return Plan. The full texts are available in the newspaper's online archives at www.informacion.es.

The analysis offered in section four will point out the main linguistic and visual elements that contribute to a particular construction of immigrants' return in this newspaper. The following elements will be analysed: the page layout, the headlines, subheadings and captions, the salience, the frames that the page has and the photograph.

\section{Analysis}

\subsection{General characteristics of the data}

Almost half of the texts analysed (45.2\%) have photographs, i.e., they combine images and written texts. According to visual grammar, their position on the page is related to their importance, the top, the central and the right of the page being the most prominent positions. $23.8 \%$ of the pieces of news appear at the top of the page and are small; $19.1 \%$ appear further down in the page, which makes them less important; $11.9 \%$ are in the centre, $9.5 \%$ on the left and $16.66 \%$ on the right. Only $14.2 \%$ consists of a whole page while $4.7 \%$ consists of two pages.

Immigrants are pictured in $31.5 \%$ of these images. They appear idle, wearing dirty or casual clothes, represented as a group instead of as individuals and not looking at the audience, as the analysis will show. On the other hand, politicians appear in $26.3 \%$ of the texts analysed, wearing good quality and clean clothes. In addition, members of NGOs appear in 15.7\%: they are clean and wear casual clothes. Moreover, in 26.3\% there are photographs of people at the airport or outside the INEM (National Institute of Employment) offices but it cannot be distinguished if they are immigrants or not.

Special attention will be paid to the relationship between representations in text and images, because their analysis will allow one to pay attention to the role of the image in the construction of meaning and to the relationship between the image and the written text, i.e., there is intersemiotic complementarity between both elements because both contribute to the creation of meaning.

The pieces of news published by Información exhibit the following characteristics: many pieces of news $(64.2 \%)$ concentrate on the number of people who have followed the Return Plan and the nationalities of the people who do so and emphasize that people from Colombia, Ecuador and Argentina are those who have followed the Plan more often. There is also a tendency to highlight the amount of money that the Government is investing in the Plan as a way to emphasize that the Government cares for immigrants not just as a policy being pursued. The majority of the pieces of news on immigrants' return in the newspaper Información present the Plan as something positive while only $7.1 \%$ criticise some of its aspects. 
The next section concentrates on a detailed description of the main linguistic and visual elements in two multimodal texts dealing with immigrants' return (see appendix one and two with the complete texts) that are representative of the representation of social actors in pieces of news related to the Return Plan proposed by the Spanish Government. The analysis refers specifically to some of the linguistic and visual characteristics described generally in this section in order to observe how these texts create their meanings. Section 4.2 deals with the main linguistic characteristics in the texts under analysis whereas section 4.3 is devoted to the main visual characteristics of the said texts following van Leeuwen's social actor analysis (2008). Finally, section 4.4 provides a summary of the main ideas presented in the whole analysis.

\subsection{Main linguistic characteristics of immigrants' return in the press}

Regarding the linguistic analysis, it will concentrate on lexis in order to observe the way immigrants and the Return Plan are referred to and to the representation of social actors. The analysis will also pay attention to the use of passive or active constructions in the headings, subheadings, the caption and the piece of news, the use of figures or statistics or to the different voices that appear in the texts.

\subsubsection{The use of the word immigrant}

The word 'immigrants' ( $84 \%$ ) is the one constantly chosen by journalists as a means of distinguishing between the majority group and immigrants who can follow the Return Plan, between 'we' and 'they'. The fact that the word immigrants is the one that appears in some headings, subheadings and in most of the examples in the written text does not contribute to offering a positive representation of immigrants because this word is linked to negative connotations, established in public discourses about immigrants, of poverty, illegality, marginality, discrimination, racism, etc. Following van Leeuwen's framework (2008: 35), this would be an example of generalization in the representation of social actors since immigrants are referred to in a generic way.

Consequently, the choice of the word immigrants is a less neutral one compared to others such as extranjeros, although in some contexts this could also be seen as negative ('foreigners', 4\%), trabajadores extranjeros ('foreign workers', $8 \%$ ) or trabajadores que vienen de un país extranjero ('workers coming from abroad', 4\%), and so makes a negative contribution to the integration of immigrants or to their representation as active members of society.

For example, in text one the references to immigrants as la cifra de potenciales beneficiarios de la medida se eleva a 87000 (the figure of the potential beneficiaries of the measure goes up to 87000) and los interesados podrán acudir a las oficinas del INEM para recabar información [...] (those interested will be able to go the offices of INEM (National Institute of Work) to get some information) are euphemistic because they avoid mentioning that those immigrants who follow 
the Return Plan are on welfare and are not in a stable socio-economic situation. In the same text it is also euphemistic to refer to immigrants as 'workers' and then specify that they have no job, as happens in the heading los trabajadores no comunitarios que quieran cobrar el paro para regresar a su país de origen ('workers from non-European countries who want to get the money from the dole in order to go back to their countries of origin') or inside the piece of news: $L a$ medida está destinada a trabajadores desempleados de los 19 países con los que España tiene firmados acuerdos bilaterales en materia de Seguridad Social ('The measure is for workers with no job from the 19 countries with which Spain has signed bilateral agreements regarding Social Security').

\subsubsection{Role allocation: immigrants as passive}

The previous paragraphs make clear that immigrants are presented as a group, i.e., they are presented as classes instead of as specific identifiable individuals (van Leeuwen 2008: 35). Moreover, in terms of role allocation (van Leeuwen 2008: 32), the analysis shows that immigrants are not represented as actors in the texts analysed; on the contrary, they are passive recipients of the situation as the heading of text two makes clear: La crisis económica obliga a 210 inmigrantes a regresar a sus paises de origen en 2009 ('The economic crisis obliges $210 \mathrm{immi-}$ grants to go back to their countries of origin in 2009'). As we can see, the subject is the economic crisis and the immigrants are the objects of the verb 'oblige', which reinforces their passive attitude. This passivization works ideologically because immigrants are always the people to whom the action is done, they are presented as participants who do nothing to contribute to the Spanish economy and are in need of socio-economic help.

In addition, the subheading in this text reinforces one of the main causes for immigrants to return, which presents them as different to the majority group because they need residence cards: La dificultad para obtener tarjetas de residencia por las escasas cotizaciones es una de las causas de los retornos ('The difficulty of obtaining a residence card due to the low quota is one of the reasons for the returns'). In this sentence, the noun phrase 'the returns' contributes to the passivization of immigrants because it is employed to disguise the immigrants, i.e., human agents are transformed into a passive process.

\subsubsection{The reinforcement of the Return Plan}

Following on from this, apart from presenting immigrants as passive, another characteristic of the written text is the importance given to the Return Plan, which contributes to highlighting the economic crisis and the socio-political context in which the Return Plan is proposed by the Spanish government (see section 1). For example, in text one, it appears as subject in three cases, which indicates that it is given importance since it appears as the agent of the action: la iniciativa [...] será un nuevo instrumento en la gestión de flujos migratorios (The initiative [...] 
will be a new instrument in the management of migratory movements), el plan permitirá a los inmigrantes percibir la prestación en dos plazos (the plan will allow immigrants to receive the money on two dates), la medida está destinada [...] (the measure is destined [...]). The previous references to the Plan are presented as positive, both for the immigrants who decide to follow it and for Spain. The implication of presenting the Plan in a positive way is to encourage immigrants to return and to please Spaniards.

\subsubsection{The use of figures}

The use of figures is another characteristic of the texts analysed, in order to indicate the number of immigrants who have followed the Plan and the amount of money invested in them. For example, 87000 (beneficiaries) is an outstanding figure found in text one and 210 (immigrants) appears in text two. Following van Leeuwen's (2008) classification of social actors, these are considered examples of assimilation because immigrants are treated as groups, more specifically, an example of aggregation (van Leeuwen 2008: 37) because immigrants are quantified and treated as statistics.

\subsubsection{Different voices}

It is remarkable that immigrants' voices are not present in any of the texts under analysis. However, there are other voices of people having power in the Spanish society. For example, in text one there is just one direct voice in this piece of news, and it belongs to Celestino Corbacho (the Spanish Minister of Work who started the Return Plan in 2008): La iniciativa, añadió, "no nace con voluntad de coyuntura sino de permanencia ("The initiative, he added, is not created as a juncture but as permanent"). This statement shows that the Spanish Government, represented by Corbacho is determined to adhere to the Return Plan. In text two, we find the direct voice of the person responsible for Communication in the Trade Union, $\mathrm{CCOO}$, pointing out the importance of creating measures to protect people who have no jobs.

In addition, in text two, there are other voices: The social worker Marta Celia Osorio says that many immigrants have to leave their flats because they cannot pay for them; she also points out that some immigrants go to the Police Station to present their letter of expulsion. Moreover, the regional secretary of the trade Union CCOO, Juan de Dios Brotons, claims that many people were helped to regularize their situation in Elda, Petrer, Sax and Monovar, four towns of Alicante, which contrasts with the statements presented in the same piece of news. Including other voices has consequences because readers can see that there are people in the Spanish society that support immigrants.

Spanish people are named and individualised from the linguistic point of view whereas immigrants remain generic and collectivised (van Leeuwen 2008: 37, 40 ), as it has been pointed out at the beginning of this section. As we can see, 
the different speakers are referred to by their names and surnames, i.e., following van Leeuwen (2008: 41) they are named in a semiformal way by giving their names and surnames, whereas the immigrants being obliged to return are referred to as 'a great number of immigrants', i.e., as an unspecified abstract group. In van Leeuwen's analysis (2008: 42), these are some examples of functionalization because the social actors mentioned are referred to in terms of the activity they do. This contrasts with immigrants, who are never presented making reference to their jobs.

The fact that immigrants' voices are not present in the texts analysed is concerned with the positioning of immigrants as 'other' to the audience, as people who are different and at a distance to the main group and therefore presented in an unequal position. In essence, the social actors that belong to the majority group in the four texts are personalised by using their proper names (Celestino Corbacho, Marta Celia Osorio, etc.) and their position or job they do (Minister, social worker, etc.), i.e., their references in the linguistic text include the feature 'human'.

However, the references to immigrants are impersonal, mainly through abstraction because they are mainly referred to as quantity (see the examples using figures and statistics above) and without any reference to their name. In this sense, immigrants are identified not by what they do but what they are (cf. van Leeuwen 2008: 42). They are, for example identified in terms of their gender, religion or provenance; in the analysis they are identified as being men who come from a different country.

\subsection{Main visual characteristics of immigrants' return in the press}

The visual analysis will pay attention to the way the different participants that appear in the selected pieces of news are represented as social actors (as groups or as individuals); we will also explore the use of colours, the expression of interactive meaning, the most salient element in each text, the different shots, the creation of visual dysphemisms and the active and passive roles given to the represented participants.

\subsubsection{Participants represented as a group or as individuals}

Following van Leeuwen's social actors analysis (2008), it is relevant that immigrants are also represented as a 'collectivised' from the visual point of view (van Leeuwen 2008: 37) (see text two) because in this text we find group shots. This implies that none of the immigrants represented is a protagonist in the piece of news worthy of particular, personalised representation. Moreover, immigrants are homogenised because most of them are represented giving their backs and not looking at the audience, and therefore not interacting with the viewers. The fact that they are all waiting and doing nothing in the street also contributes to their homogeneisation because they are represented performing the same action. This contrasts with the representation of the Minister (see text one) from the visual point of view. 
Corbacho is the only person represented in the visual and therefore, as it can be observed linguistically, this is another example of individualisation (van Leeuwen 2008: 37). The representation of the Minister shows that he has power and is the protagonist of the piece of news due to the measures he has taken related to the Return Plan. Close shots foreground the individuality of the Minister.

\subsubsection{Interaction and distance in the photographs}

Although the photograph in text one is small, it shows a very clear interactive meaning because the Minister appears close to the audience by looking to the readers and requesting an answer from them. The most salient elements in this visual are the use of colours and the fact of presenting just one participant that is the only actor in the piece of news, which contrasts with the visual found in text two.

In text one the Minister's eye that can be seen (i.e., he covers part of his face with his right hand) looks directly at the readers, and therefore there is interaction between the Minister and the audience. The fact that he knits his brow and that half of his face is covered indicates that he is thinking. If he is in a press conference, he looks uncomfortable and not confident. Perhaps he felt harassed by the journalists' questions about this non popular Plan.

Since there is no eye contact between immigrants and readers in text two, it is suggested that the viewers are active in relation to the immigrants and that there is a social or interpersonal distance from the audience, which makes them apart from the main group in society, i.e., the Spanish population. There is a visual suggestion that immigrants feel ashamed of their situation and also are detached from and inferior to the main group, being unworthy of personalized representation. The world of immigrants and the reality showed in this photograph is presented as different from local people's daily life. In this way, there is a clear distinction between them and their problems and us and our situation, in which 'we do not face the problems they do'.

The presentation of immigrants as not looking at the audience avoids any possibility of dialogue and promotes their representation as distant from the audience and not willing to establish any social relation. This distance is a visual strategy to represent people as 'others', in van Leeuwen's words (2008: 141): “[ ...] the strategy of distanciation, representing people as 'not close to us', as 'strangers"'.

\subsubsection{Deconstructing visual dysphemisms}

Text two shows immigrants as a group of people; they are idle and queuing outside the Immigration Office in Alicante. Representing immigrants not doing anything suggests that they are unemployed and thus a drain on the Spanish social system and that they lack agency (i.e., they are passive). The immigrants represented in the image display certain characteristics of social exclusion, which allows us to talk about visual dysphemism': firstly, as mentioned above, 
the photograph is black and white, which contrast with the coloured photograph found in text one; secondly, the fact that the people represented have their backs turned to the viewer contributes to their social exclusion since there is no social relation with the audience, as the following paragraphs will explain. In contrast with the interactive photograph of Minister Corbacho, immigrants are represented participants that do not interact with the viewer - as objects, rather than as persons.

In addition, in text two, there are three sections: in the foreground there are two people turning their backs, in the middle distance, we find the people closer to them on the right and on the left and finally, in the background there are people who are further away in the queue. The fact that no immigrant looks at the reader (the third immigrant on the left is looking down) and that there are two participants turning their backs (the first person on the right and the woman in the centre), again presents the immigrants as having no interaction with the audience and keeping their distance, which is symbolic in pictures, as van Leeuwen (2008: 138) makes clear: "People shown in a "long shot", from far away, are shown as if they are strangers; people shown in a "close up" are shown as if they are "one of us".

Observing immigrants in a long shot thus contributes to presenting them as strangers whereas presenting the Minister of Work in a close-up shows him as one of us, a person who belongs to the main group. In addition, immigrants in text two are depicted as socially below us because we see them from the horizontal angle, as the observed, i.e., from the side instead of the vertical angle from which we observe the Minister at eye level in texts one. It is significant that the woman in the centre of text two wears a short skirt and shows part of her back. She is showing part of her body and is standing, which evokes the image of unemployed people, standing up without doing anything.

\subsubsection{Active and passive roles in the visuals}

The visual analysis presented in the previous paragraphs is helpful in order to observe who are the participants having an active role of doing or/and looking (i.e. the Minister of Work in text one) and those who have a passive roles (i.e., the immigrants portrayed in text two). In conclusion, there is a major contrast between the photograph found in the first text in which the Minister is represented showing his face (partly covered by his hand in text one) and wearing smart clothes, and the image in text two that can be considered a visual dysphemism because immigrants are represented as excluded. On the one hand, politicians are represented wearing smart clothes and their voices are present in the newspaper Información, as the analysis of text one makes clear; on the other hand, text two shows that immigrants are represented idle in the streets, turning their backs to the audience, and distant from the viewers, which avoids any possibility of interaction and makes the reader active in comparison with them, and therefore possessing more power.

Moreover, immigrants are represented as patients with respect to the given action and assimilated and associated since they are all presented together as 
a group of anonymous individuals (van Leeuwen 2008: 37-39), as members of a general class, which contrasts with the representation of the Minister Corbacho as a specific person - and therefore with agency - in texts one.

\subsection{Key ideas in the analysis}

The texts analysed show no positive characteristic of immigrants in the linguistic or in the visual text. On the contrary, the immigrants are represented as excluded from the main group. Arguably, this exclusion is not merely incidental: it is related to the strategy of the paper to present the immigrants in a negative light and to legitimate the proposed plan to repatriate them to their countries of origin. This form of representation is, thus, functional - as van Leeuwen (2008: 28), for instance, observes, "Representations include or exclude social actors to suit their interests and purposes in relation to the readers for whom they are intended".

One of the main differences between the texts analysed is in the representation of social actors (van Leeuwen 2008). The different participants in the pieces of news can be referred to as individuals or as in groups. As Machin and van Leeuwen (2005: 132) make clear: "Which of these two options is chosen can make a significant difference to the way events are represented". Linguistically, immigrants are represented by means of the strategy of 'collectivisation' since they are referred to with nouns denoting a group of people (immigrants, workers, etc.) or as statistics. On the contrary, the analysis shows the individualisation of politicians and officialdom since they are referred to by their names and their position. 5. Discussion: the function of the media and elite racism

The different linguistic and visual characteristics analysed in the texts presented in section 4.2 and 4.3 demonstrate that the press has power to influence on society because there is a relationship between the different choices and the representation and exercise of power. When the Government or the press want to indicate that there are too many immigrants or that they do not benefit our society, the main group's positive characteristics are highlighted (van Dijk 2003: 118; Wimmer 2000: 48).

In addition, immigrants are represented negatively, creating a discourse of exclusion, in van Dijk's words (2005: 28): "Therefore, in the overall strategy of negative other-representation and positive self-presentation, one of the most powerful moves of anti-immigrant discourse is to claim or to show that antiimmigrant policies are good for 'Us' or 'our people". This has been observed in the analysis already presented where the Minister of Work presents the Plan as a positive measure created to assist immigrants whereas they are represented as those in need of help, without referring to any of their positive characteristics. The division between 'we' and 'they' contributes to 'elite racism'.

The representation of immigrants shown in the previous sections contributes to the creation of a new racism. It is characterized by the exclusion of those who for a few years were active citizens, had their jobs, bought their houses, paid Social Security and had contributed to the Spanish economy. In other words, the 
immigrants who are invited to go back to their countries of origin following the Return Plan have the right to receive money from the dole because they worked for long periods of time before the crisis, i.e., they had acquired the right of receiving social benefits because they had contributed actively to the social and economic life of Spain. These complexities in appraising their situation, however, rarely appear in the media discussion.

\section{Conclusions}

The news items analysed show that the newspaper Información legitimates the Return Plan by referring to it as something positive for workers of migrant backgrounds and for Spain. In this way, this newspaper aligns itself with the Governmental spin. Información uses different linguistic and visual strategies in order to legitimate the Return Plan (see section 4). For example, referring to people coming from abroad as immigrants so many times, in the texts analysed, contributes to their social exclusion due to the connotations of the term: it is normally associated with discrimination, poverty, not possessing legal documents, etc. This word is not semantically associated with social dignity. And, importantly, it defines them as a distinct, separate entity, to which such connotations may then be attached. Moreover, the visual dysphemisms analysed do not favour the social integration of immigrants. The lexical and visual elements analysed show the journalists' negative view on immigrants.

The return of immigrants in the said newspaper is linked with invisibility in two senses: on the one hand, elite racism is present in the newspaper' items of news in this respect while immigrants' voices are silenced and consequently, their opinions are not taken into consideration. On the other hand, the Return Plan is not such a positive measure as it seemed at first and therefore, the number of immigrants who follow it are not as many as expected. This is politically important in the context of contemporary Spanish politics because their return is understood as one of the solutions to the unemployment problem in the country since more than five million people do not have a job at the moment.

The texts analysed indicate that there are two realities in the pieces of news on the return of immigrants: first, the reality of the majority group, the group having power, represented by politicians, who are the ones who take the decisions; second, the reality of the minority group, of the immigrants who are invited to follow the Return Plan and who are the ones who have to respect the decisions taken by the dominant group. In this sense, the reality of the main group can be considered superior to the reality of the minority group. Ostensibly, the Return Plan's purpose is to help immigrants having no job to go back to their countries of origin but it is only the immigrants who have been legally and gainfully employed who can get funding for return. 


\section{Notes}

1 Dysphemism is understood as the process whereby the most pejorative traits of the taboo are highlighted with the aim of giving offence to the addressee or to the concept itself. Consequently, the term visual dysphemism will be used to refer to these cases in which images illustrate the pejorative side of a social reality or group of people, in this case of immigrants (Crespo and Martínez Lirola 2012).

\section{References}

Alonso Belmonte, Isabel, Anne McCabe and Daniel Chornet-Roses (2010) "In their own words: The construction of the image of immigrant in Peninsular Spanish broadsheets and freesheets". Discourse and Communication 4 (3), 227-242.

Baldry, Anthony (ed.) (2000) Multimodality and Multimediality in the Distance Learning Age. Campobasso: Palladino Editore.

Baldry, Anthony and Paul J. Thibault (2006) Multimodal Transcription and Text Analysis. London: Equinox.

Bañón Hernández, Antonio Miguel (2002) Discurso e inmigración. Propuestas para el análisis de un debate social. Murcia: Universidad de Murcia.

Bañón Hernández, Antonio Miguel (2007) "El discurso periodístico a propósito del viaje de los inmigrantes pobres". In: Zapata-Barrero, Ricard and Teun A. van Dijk (eds.) Discursos sobre la inmigración en España. Los medios de comunicación, los parlamentos y las administraciones. Barcelona: Fundación CIDOB, 45-67.

Blázquez Vilaplana, Belén (coord.) (2013) Actas del Seminario Internacional: Retorno de los/as inmigrantes a sus países de procedencia u origen. Estado de la cuestión. Jaén: Servicio de Publicaciones de la Universidad.

Borchers, Timothy A. (2002) Persuasion in the Media Age. Boston: McGraw Hill.

Caldas-Coulthard, Carmen Rosa (2002) "Cross-cultural representation of 'otherness' in media discourse". In: Weiss, Gilbert and Ruth Wodak (eds.) Critical Discourse Analysis: Interdisciplinary Perspectives. London: Macmillan, 272-296.

Checa, Francisco (ed.) (2008) La inmigración sale a la calle. Comunicación y discursos políticos sobre el fenómeno migratorio. Barcelona: Icaria.

Chouliaraki, Lilie (2007) "Introduction: the soft power of war: Legitimacy and community in Iraq war discourses". In: Chouliaraki, Lilie (ed.) The Soft Power of War. Amsterdam and Philadelphia: John Benjamins, 1-10.

Chovanec, Jan (2010) "Legitimation through differentiation. Discursive construction of Jacques Le Worn Chirac as an opponent to military action". In: Okulska, Urszula and Piotr Cap (eds.) Perspectives in Politics and Discourse. Amsterdam and Philadelphia: John Benjamins, 61-81.

Conway, Dennis and Robert B. Potter (eds.) (2009) Return Migration of the Next Generations. Aldershot, UK and Burlington USA: Ashgate.

Cottle, Simon (2000) "Introduction. Media Research and Ethnic Minorities: Mapping the Field". In: Cottle, Simon (ed.) Ethnic Minorities and the Media. Philadelphia: Open University Press, $2-30$.

Crespo, Eliecer and María Martínez Lirola (2012) "Lexical and visual choices in the representation of immigration in Spanish press". Spanish in Context 9 (1), 27-57.

Fairclough, Norman (1995) Media Discourse. London: Arnold.

Fairclough, Norman (2003) Analysing Discourse. Textual Analysis for Social Research. London: Routledge.

Fowler, Roger (1991) Language in the News: Language and Ideology in the Press. London: Routledge. 
Granados, Antolín (1998) La imagen del inmigrante extranjero en la prensa española. ABC, Diario 16, El Mundo y El País. Periodo 1985-1992. Granada: Universidad de Granada.

Información (1 September 2008 to 28 February 2011). http://www.informacion.es

Jewitt, Carey (ed.) (2009) The Routledge Handbook of Multimodal Analysis. London: Routledge.

Kress, Gunther (2003) Literacy in the New Media Age. London: Routledge.

Kress, Gunther and Teun van Leeuwen (2001) Multimodal Discourse: The Modes and Media of Contemporary Communication. London: Arnold.

Kress, Gunther and Teun van Leeuwen (2006) Reading Images: The Grammar of Visual Design, $2^{\text {nd }}$ ed. London: Routledge Press.

Long, Lynellyn D. and Ellen Oxfeld (eds.) (2004) Coming Home?: Refugees, Migrants, and Those who Stayed Behind. Philadelphia: University of Pennsylvania Press.

Martin, James R. and David Rose (2007) Working with Discourse. Meaning beyond the Clause, $2^{\text {nd }}$ ed. London: Continuum.

Martínez Lirola, María (2006) "A Critical Analysis of the Image of Immigrants in Multimodal Texts". Linguistics and the Human Sciences 2 (3), 377-397.

Martínez Lirola, María (2008) "Las relaciones entre las características lingüísticas y visuales de las noticias sobre inmigración en la prensa gratuita y su relación con la audiencia". Discurso y Sociedad 2 (4), 799-815.

Martínez Lirola, María (2009) "Immigration news in the free press: linguistic and the visual characteristics". Brno Studies in English 35 (1), 63-76.

Martínez Lirola, María (ed.) (2010) Migraciones, discursos e ideologías en una sociedad globalizada. Claves para su mejor comprensión Alicante: Instituto Alicantino de Cultura Juan Gil Albert.

Martínez Lirola, María (2013) "Immigrants going back home: an analysis of the discursive representation of the return plan for immigrants in three Spanish newspapers". In: Martínez Lirola, María (ed.) Discourses of Immigration in Times of Economic Crisis: A Critical Perspective. Newcastle upon Tyne: Cambridge Scholars Publishing, 1-27.

Martínez Lirola, María (2014) "Approaching the representation of Sub-Saharan immigrants in a sample from the Spanish press: deconstructing stereotypes". Critical Discourse Studies 11 (4). 482-499.

Machin, David and Theo van Leeuwen (2005) "Computer games as political discourse. The case of Black Hawk Down". Journal of Language and Politics 4 (1), 119-141.

Nash, Mary (2001) Diversidad, multiculturalismos e identidades: perspectivas de género. In: Mary Nash and Diana Marre (eds.) Multiculturalismos y género: perspectivas interdisciplinarias. Barcelona: Bellaterra, 21-47.

O'Toole, Michael (2011[1994]) The Language of Displayed Art. London and New York: Routledge.

Red Europea de Migraciones (2009) Programas y estrategias referentes al retorno asistido y reintegración de los emigrantes a terceros países. Madrid: Observatorio Permanente de la Inmigración y Red Europea de Migraciones.

Reisigl, Martin and Ruth Wodak (2001) Discourse and Discrimination. Rhetorics of Racism and Antisemism. London: Routledge.

Renkema, Jan (2009) The Texture of Discourse. Amsterdam and Philadelphia: John Benjamins.

Retis, Jessica (2010) “¿Cómo reflejan los medios de comunicación a las mujeres inmigrantes latinoamericanas? Análisis de la prensa española y estadounidense". In: Martínez Lirola, María (eds.) Migraciones, discursos e ideologías en una sociedad globalizada. Claves para su mejor comprensión. Alicante: Instituto Alicantino de Cultura Juan Gil Albert, 57-77.

Royce, Terry D. and Wendy L. Bowcher (eds.) (2007) New Directions in the Analysis of Multimodal Discourse. London: Lawrence Erlbaum Associates.

Talbot, Michael M. (2003) "Women Rule as a Matter of Fact': Reproducing and Challenging Gender Stereotypes”. In: Santaemilia, José (ed.) Género, lenguaje y traducción. Valencia: Universidad de Valencia, 26-41.

Thompson, John B. (1990) Ideology and Modern Culture. Critical Social Theory in the Era of Mass Communication. Cambridge: Polity Press. 
Van Dijk, Teun A. (1987) Communicating Racism. Ethnic Prejudice in Thought and Talk. London: Sage Publications.

Van Dijk, Teun A. (1993) Elite Discourse and Racism. London: Sage Publications.

Van Dijk, Teun A. (2003) Dominación étnica y racismo discursivo en España y América Latina. Barcelona: Gedisa.

Van Dijk, Teun A. (2005) Racism and discourse in Spain and Latin America. Amsterdam and Philadelphia: John Benjamins.

Van Dijk, Teun A. (2006) "Discurso de las élites y racismo institucional". In: Lario Bastida, Manuel (ed.) Medios de comunicación e inmigración. Murcia: Convivir sin Racismo: CAM - Obra Social, 16-34.

Van Dijk, Teun A. (2007) "Racismo y discurso en América Latina: una introducción”. In: van Dijk, Teun A. (ed.) Racismo y discurso en América Latina. Barcelona: Gedisa, 21-34.

Van Dijk, Teun A. (2008) "Reproducir el racismo: el rol de la prensa". In: Checa y Olmos, Francisco (ed.) La inmigración sale a la calle. Comunicación y discursos políticos sobre el discurso migratorio. Barcelona: Icaria, 19-49.

Van Leeuwen, Theo and Carey Jewitt (2000) The Handbook of Visual Analysis. London: Sage Publications.

Van Leeuwen, Theo (2005) Introducing Social Semiotics. New York: Routledge.

Van Leeuwen, Theo (2007) "Legitimation in discourse and communication". Discourse \& Communication 1, 91-112.

Van Leeuwen, Theo (2008) Discourse and Practice. New Tools for Critical Discourse Analysis. Oxford: Oxford University Press.

Van Leeuwen, Theo (2009) "Critical Discourse Analysis". In: Renkema, Jan (ed.) Discourse, of Course. An Overview of Research in Discourse Studies. Amsterdam and Philadelphia: John Benjamins, 277-292.

Wimmer, Andreas (2000) "Racism in Nationalised States: a Framework for Comparative Research". In: ter Wal, Jessika and Michael Verkuyten (eds.) Comparative Perspectives on Racism. Aldershot: Ashgate, 47-72.

Wodak, Ruth and Michael Reisigl (2001) "Discourse and Racism". In: Tannen, Deborah Schiffrin and Heidi Hamilton (eds.) The Handbook of Discourse Analysis. Oxford: Blackwell, 372-397.

Woods, Nigel (2007) Describing Discourse. A Practical Guide to Discourse Analysis. Oxford: Oxford University Press.

Zapata Barrero, Ricard (2008) "Fundamentos de las políticas del discurso sobre la inmigración". In: Hernández, Antonio Bañón and Javier Fornielles (eds.) Manual de comunicación e inmigración. San Sebastián: Tercera Prensa, 429-451. 


\section{Appendixes}

Text 1. Los inmigrantes podrán acogerse al plan de retorno a partir de finales de octubre. 20-09-2008. Newspaper: Información.

\section{Los inmigrantes podrán acogerse al plan de retorno a partir de finales de octubre}

EFE. MADRID

- Los trabajadores no comunitarios que quieran cobrar el paro para regresar a su país de origen deberán esperar hasta finales de octubre o noviembre para hacerlo, según una iniciativa aprobada ayer por el Gobierno con carácter permanente. Así lo anunció el ministro de Trabajo e Inmigración, Celestino Corbacho, tras la aprobación en Consejo de Ministros del decreto ley relativo al retorno voluntario de inmigrantes, que se tramitará en el Parlamento por vía de urgencia.

La iniciativa, añadió, «no nace con voluntad de coyuntura sino de permanencia» y será un nuevo instrumento en la gestión de los flujos migratorios.

Según sus cálculos, la cifra de potenciales beneficiarios de la medida se eleva a 87.000 , con una duración media de la prestación del paro que oscila entre los 6 y los 18 meses.

El plan permitirá a los inmigrantes percibir la prestación en dos plazos: el $40 \%$ en España, una vez reconocido el derecho, y el $60 \%$ en el país de origen, transcurridos treinta días naturales desde el primer pago.

A partir de la semana próxima, los interesados podrán acudir a las oficinas del INEM para recabar información, aunque no será hasta finales de octubre o princi-



El ministro Celestino Corbacho

pios de noviembre cuando el derecho sea efectivo, subrayó el ministro.

La medida está destinada a trabajadores desempleados de los 19 países con los que España tiene firmados convenios bilaterales en materia de Seguridad Social, pero el decreto ley deja abierta la opción de negociar con otros países interesados si garantizan cierta cobertura sanitaria y social. También menciona la posibilidad de que el Ministerio de Asuntos Exteriores y de Cooperación dialogue con los países para ofrecer otro tipo de ayudas complementarias. 
Text 2. La crisis económica obliga a 210 inmigrantes a regresar a sus países de origen en 2009. 25-06-2009. Newspaper: Información.

\section{La crisis económica obliga a 210 inmigrantes a regresar a sus países de origen en 2009}

La dificultad para obtener tarjetas de residencia por las escasas cotizaciones es una de las causas de los retornos

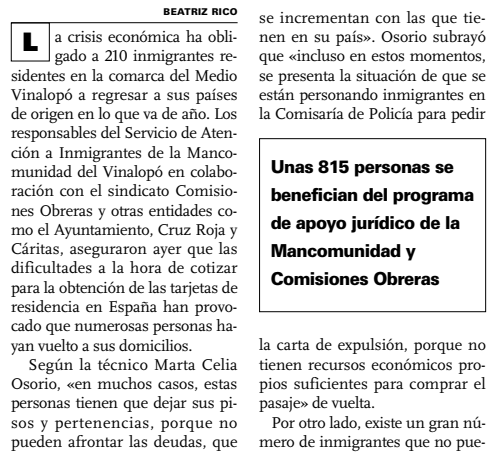

den regresar a sus lugares de origen «porque no se les acepta la solicitud al tener hijos españoles o causas pendientes con la Justicia», dijo Osorio.

El retorno voluntario es uno de los temas que se tratan en este convenio de colaboración que pretende prestar una atención personalizada y de apoyo jurídico, así como asesoramiento e información sobre los aspectos legales en materia de extranjería como puedan ser los trámites a seguir y los procedimientos que con carácter general están establecidos. La población atendida ha sido de diferentes nacionalidades, como BraChile, Cuba, Rusia, Guatemala o Venezuela. De igual forma, también se ha atendido a ciudadanos

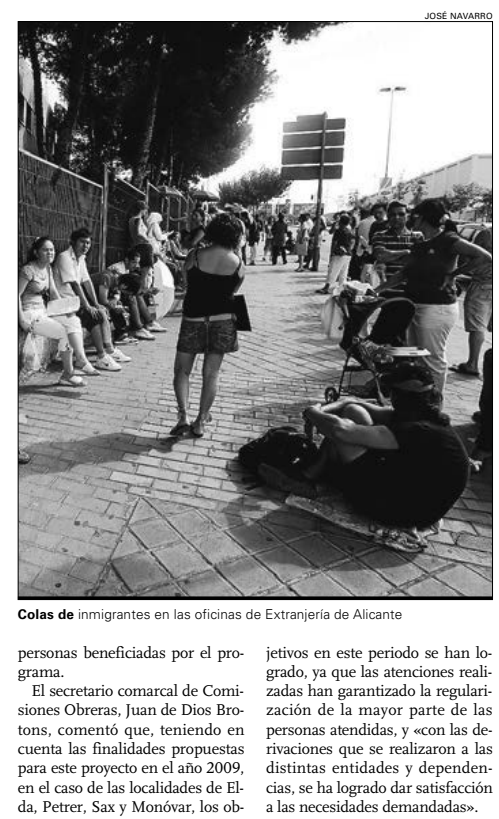

María Martínez Lirola is Professor of the Department of English Studies at the University of Alicante, Spain and Research Fellow at the University of South Africa (UNISA). Her main areas of research are Critical Discourse Analysis, Systemic Functional Linguistics and Applied Linguistics. She has published more than 70 papers and seven books, such as Main Processes of Thematization and Postponement in English (Peter Lang, 2009). She has been a visiting scholar in different universities such as: Carleton University (Ottawa, Canada, 2012), University of South Africa, UNISA (Pretoria, South Africa, 2012), University of Anahuac Mayad (Mérida, Mexico, 2008), University of Kwazulu-Natal (Pietermaritzburg, South Africa, 2006), and Macquarie University (Sydney, Australia, 2005). She has presented papers in international congresses all over the world.

Address: Professor María Martínez Lirola, University of Alicante and Research Fellow, Department of Linguistics and Modern Languages, University of South Africa (UNISA), Department of English Studies, University of Alicante, Ap.99 E-03080 Alicante, Spain [email: maria.lirola@ua.es] 
